\title{
МІЖНАРОДНИЙ ТУРИЗМ В УМОВАХ ПАНДЕМІї: ПРОБЛЕМИ ТА ШЛЯХИ ПОДАЛЬШОГО РОЗВИТКУ
}

\section{INTERNATIONAL TOURISM IN A PANDEMIC: PROBLEMS AND WAYS FOR FURTHER DEVELOPMENT}

\author{
Тюріна Діна Миколаївна \\ кандидат педагогічних наук, доцент, \\ Національний університет цивільного захисту України \\ ORCID: https://orcid.org/0000-0002-1506-5849 \\ Tiurina Dina \\ National University of Civil Defense of Ukraine
}

\begin{abstract}
У статті розглядається аналіз тенденцій розвитку сорери туризму за сучасних умов та впливу COVID-19 на індустрію туризму. Визначено, що туристична індустрія має важливе значення для розвитку держави. Тенденції розвитку міжнародного туризму визначаються впливом зовнішніх і внутрішніх фракторів на галузь, що склалися на ринку послуг кон'юнктури попиту. В попереднє десятиліття українська індустрія туризму демонструвала стійкий розвиток як внутрішнього туризму, так і зовнішнього. Але в 2020 році через наслідки пандемії COVID-19 склалася негативна для індустрії ситуація. Економічні процеси в усіх галузях, в тому числі і туристичній, пов'язані з епідеміологічною безпекою країн світу. Індустрія туризму, готельний бізнес і заклади харчової промисловості в умовах сьогодення стикаються з величезними проблемами (всі ці ссрери «заморожені», а згодом можуть бути ліквідовані). Була виявлена необхідність не тільки підтримки суб'єктів галузі, а й створення умов для успішного відновлення їх діяльності в довгостроковій перспективі. Глобальний і локальний контекст спалаху, її наслідки та пропозиції з швидкого відновлення (стратегічні та тактичні цілі) відображені в цій статті.
\end{abstract}

Ключові слова: тенденції, туризм, пандемія COVID-19, виклики, проблеми.

В статье рассматривается анализ тенденций развития сферы туризма в современных условиях и влияния COVID-19 на индустрию туризма. Определено, что туристическая индустрия имеет важное значение для развития государства. Тенденции развития международного туризма определяются влиянием внешних и внутренних фракторов на отрасль, сложившиеся на рынке услуг конъюнктуры спроса. В предыдущее десятилетие украинская индустрия туризма демонстрировала устойчивое развитие как внутреннего туризма, так и внешнего. Но в 2020 году из-за последствий пандемии COVID-19 сложилась отрицательная для индустрии ситуация. Экономические процессы во всех отраслях, в том числе и туристической, связанные с эпидемиологической безопасностью стран мира. Индустрия туризма, гостиничный бизнес и заведения пищевой промышленности в сегодняшних условиях сталкиваются с огромными проблемами (все эти ссеры «заморожены», а впоследствии могут быть ликвидированы). Была выявлена необходимость не только поддержки субъектов отрасли, но и создание условий для успешного восстановления их деятельности в долгосрочной перспективе. Глобальный и локальный контекст вспышки, ее последствия и предложения по быстрому восстановлению (стратегические и тактические цели) отражены в этой статье.

Ключевые слова: тенденции, туризм, пандемия COVID-19, вызовы, проблемы.

The article examines the analysis of trends in the development of the tourism sector in modern conditions and the impact of COVID-19 on the tourism industry. It is determined that the tourism industry is important for the development of the state. Trends in the development of international tourism are determined by the influence of external and internal factors on the industry, the prevailing market conditions of demand for services. In the previous decade, the Ukrainian tourism industry has demonstrated a steady development of both domestic tourism and foreign tourism. Tourism is an important area of socio-economic activity and brings significant contribution to state budget revenues in many countries. But in 2020, due to the consequences of the COVID-19 pandemic, a negative situation has developed for the industry. Economic processes in all sectors, including tourism, related to the epidemiological security of the countries of the world. The tourism industry, hotel business and food industry establishments in today's conditions are faced with enormous problems (all these areas are suspended, and subsequently may be liquidated). The need was identified not only to support the subjects of the industry, but also to create conditions for the successful restoration of their activities in the long term. The global and local context of the outbreak, its aftermath 
and proposals for rapid recovery (strategic and tactical goals) are reflected in this article. The research is based on analytical, statistical and forecast materials of the World Tourism Organization (UNWTO), Organization for Economic Cooperation and Development (OECD), World Travel and Tourism Council (WTTC). The following research methods were used: system analysis - a method that is a sequence of actions to establish structural links between various elements of the system under study. Synthesis is the process of combining separate things and concepts into one whole. Induction is a research method in which a general conclusion is built on the basis of individual elements. Comparison, for the purpose of which the similarity and difference of objects and phenomena are established according to essential characteristics.

Keywords: trends, tourism, COVID-19 pandemic, challenges, problems.

Постановка проблеми. Слід зауважити, що міжнародний туризм $є$ одним 3 найбільш постраждалих в результаті поширення пандемії COVID-19 серед інших секторів глобальної економіки. Введення в кожній державі жорстких санітарних обмежень на подорожі, відкладання сезону відпочинку, закриття кордонів зумовило різке скорочення попиту на характерні і супутні туристичні послуги, а також визначило негативні тенденції розвитку міжнародного туризму в цілому. Введені обмеження істотно вплинули на загальну динаміку показників господарювання суб'єктів туристичної діяльності, а також привели до значних обсягів збитків, чимало ліквідованих підприємств на ринку туристичних послуг. Дослідження шляхів відновлення фрункціонування туристичної сорери в умовах пандемії COVID-19, а також після зняття жорстких карантинних обмежень, пошук шляхів виходу з системної кризи, обґрунтування механізмів регулювання туристичної діяльності в нових реаліях існування світової спільноти набувають зараз особливої актуальності.

Аналіз останніх досліджень і публікацій. Питання, що присвячені проблемам та перспективам розвитку міжнародного туризму, чинникам впливу на міжнародний туризм, соціально-економічному значенню міжнародного туризму висвітлені у роботах багатьох вітчизняних вчених, серед яких чималий внесок у розгляд цієї проблематики здійснили такі з них, як Красовський С.О., Дутка Г.Я., Гальків Л.І., Козак Б.Б. [3].

Виділення невирішених раніше частин загальної проблеми. Дослідження цих вчених мають фрундаментальний характер, що охоплюють проблеми та перспективи розвитку туризму тощо. Але питання тенденцій розвитку сорери туризму за сучасних умов та впливу пандемії COVID-19 на індустрію туризму в Україні висвітлені недостатньо.

Формулювання цілей статті (постановка завдання). Основною метою дослідження $€$ визначення тенденцій і закономір- ностей розвитку міжнародного туризму і можливих сценаріїв його розвитку в результаті пандемії. 3 огляду на мету дослідження поставлено ряд завдань, що дозволяють структурувати дослідження на кілька завдань: оцінити ступінь впливу пандемії на міжнародний туристичний ринок та визначити попередні сценарії виходу туристкою індустрії з кризи.

Виклад основного матеріалу дослідження. Пандемія завдала серйозного удару по всім секторам економіки, але однією 3 найбільш постраждалих галузей стала туристична сорера. Карантин, що охопив практично всі країни світу, змусив людей забути про подорожі.

3 огляду на карантинні обмеження, пов'язаних 3 коронавірусом, кордони більшості країн зараз закриті або відкриті, але 3 певними обмеженнями (обсервація 10-14 днів або ПЛР-тест, що несе за собою значні витрати), виключення - лише крайні випадки. Власне сорера туризму знаходиться на паузі і як результат величезні збитки в цій сорері і, відповідно, проблеми з наповненням державних бюджетів. Найбільш серйозні економічні руйнування будуть відзначені в малих острівних державах, в яких туризм вносить найбільший вклад в ВВП (Британські Віргінські острови - 92\% (60 островів і коралових рифрів), острів Аруба - 85,6\%, Мальдівські острови - 75,1\%, Сейшельські острови - 64,2\%, Багамські острови - 48,4\% тощо). Разом з тим, значно знизився рівень вкладу туризму у ВВП і в країнах, що входять в 20 найбільших економік світу. Це такі держави, як Таїланд, Філіппіни, Мексика тощо, які покладаються на туризм більше ніж на одну п'яту свого ВВП. Дві найбільш постраждалі країни від спалаху пандемії - це Іспанія і Італія, також сильно залежать від цієї сфрери. Несуть не малі збитки компанії-туроператори, турагенти, авіаперевізники, власники готельно-ресторанного бізнесу. Туроператори змушені повертати гроші туристам за викуплені тури, в окремих випадках, якщо 
пощастить, то переносять бронювання на більш пізні дати. Авіаперевізники також позбулися свого єдиного доходу, але при цьому, їм потрібні кошти для того, щоб оплачувати стоянку літаків, їх обслуговування тощо. що стосується готелів і закладів харчування, то до них пред'являється все більше вимог (постійна дезінсрекція, відвідувати заклади з дотриманням маскового режиму та тільки на відкритому просторі). Після завершення пандемії діючі готелі повинні відповідати всім санітарно-епідеміологічним вимогам, що будуть контролюватися суворіше, ніж зазвичай.

Міжнародний туризм грає важливу роль в структурі ВВП України. Згідно зі Всесвітнім звітом конкурентоспроможності подорожей і туризму, в 2018 році загальний внесок туризму і подорожей в економіку України склав близько 5,5 млрд дол., або 5,7\% ВВП (в 2019 році - 5,2\%) [1].

Загальна сума надходжень до місцевих бюджетів від сплати туристичного збору в Україні 2020 року становила 130,6 млн гривень. Лідером став Київ із 34,7 млн гривень. Про це повідомляє Державне агентство розвитку туризму у Facebook 3 посиланням на дані Державної податкової служби України.

У трійці лідерів опинилися місто Київ 34,7 млн грн, Одеська - 15,2 млн грн та Львівська області - 11,8 млн грн. Одразу за ними у списку - Київська область 3 9,8 млн грн. Також до топ-10 увійшли Харківська - 6,6 млн грн, Закарпатська 6,4 млн грн, Запорізька - 6,2 млн грн, ІваноФранківська та Дніпропетровська області - по 5,6 млн грн. Замикає десятку лідерів Миколаївська область 3 4,6 млн грн [2].

У найближчому майбутньому перед працівниками в сорері туризму стоїть багато завдань. Основна 3 них - відновлення в'їзного туризму в нашу країну після самоізоляції. Однією із запропонованих заходів туризму є пом'якшення візового режиму, на думку агентства, посприяє притоку туристів з-за кордону. Багато туроператорів і інші фахівці підтримують ідею, і думають, що візові фрормальності завжди були проблемою для гостей з-за кордону. Після завершення пандемії багато туроператорів роблять ставки на розвиток внутрішнього туризму. Експерти вважають, що відновлення виїзного туризму можна чекати ще багато місяців, тому слід приділити увагу новим напрямкам всередині своєї країни. Доцільним в цій ситуації буде розвивати і просувати еколо- гічні тури, індивідуальні сімейні подорожі 3 розміщенням в фрермерських будиночках, невеликих поселеннях. Таким чином, туристи отримуватимуть бажаний відпочинок в умовах часткової ізоляції від великого скупчення людей (наприклад, екоагротуризм). Такий метод буде ефективний до повної нормалізації ситуації, коли поступово почнуть відкриватися масові напрямки. У нинішній ситуації зі значними труднощами зіткнулися керівники туристичних фрірм. Для них зараз важливо зробити все можливе, щоб залишитися на ринку туристичних послуг, зазнавши мінімальні втрати. Розуміючи це, слід розробити ряд заходів, спрямованих на підтримку туристичної індустрії:

1. Підвищення конкурентоспроможності та стійкості (розвиток туристичної інфрраструктури та підвищення якості послуг та сорери обслуговування, розширення туристичних продуктів і ринків, просування внутрішнього туризму).

2. Екологізація (сприяння сталому розвитку, розвиток агроекотуризму).

3. Пом'якшення соціально-економічних наслідків (збереження робочих місць, зміцнення довіри і безпеки, податкові послаблення, виплату щомісячної допомоги в розмірі співробітникам, які були відправлені у вимушену відпустку без збереження заробітної плани, надання можливості підприємствам отримати цільовий безвідсотковий кредит для виплат заробітної плати).

4. Діджіталізація (цифровізація туристичної екосистеми, створення інноваційних рішень, інвестиції в циорровізацію).

5. Координація та міжнародне партнерство для трансорормації сектора і досягнення цілей сталого розвитку [5].

До моменту закінчення карантинних заходів та зняття введених обмежень національні органи по туризму повинні застосувати глобальний маркетинг і брендинг, який систематично оцінює і аналізує стан туризму в країні з належним виділенням кращих світових практик, що застосовуються в кризових ситуаціях з минулого, майбутніх прогнозів, щоб стимулювати туристичні потоки. Крім того, локально-глобальна співпраця має важливе значення в процесі відновлення. Повинний бути тісний зв'язок між готельним і туристичним бізнесом, допоміжними службами, місцевими відділами туризму, а також підтримувати взаємодію з органами охорони здоров'я для подальшого моніторингу регіонів. Місцеві жителі та інші важливі учасники 
туристичного процесу повинні бути добре проінсормовані і мотивувати до дотримання всіх норм і правил, щоб мінімізувати суспільну невизначеність і ризики. Глобалізація і технологічна революція надали нам багато інструментів, які тепер повинні есрективно використовуватися, щоб прокласти шлях до постпандемійному туризму.

Туризм особливо схильний до зовнішніх впливів (наприклад, в умовах сьогодення вплив світової пандемії COVID-19, недостатній рівень безпеки туристів, високий рівень терористичної загрози), що за своєю природою несподівані і повинні бути усунені за допомогою ефрективних процесів управління кризами. Такі проблеми, як ДТП, стихійні лиха, терористичні акти і спалах інфекційних захворювань, мають величезний вплив на індустрію туризму. Те ж саме можна сказати і про інциденти, таких як загроза вибуху бомби в автобусі, що курсує в регіональному центрі, розливу насти в порту або на рифрі, землетрусу на курорті, аварії потягу тощо. Всі ці фрактори порушують фрункціонування регіональних туристичних організацій і вимагають заходів з боку регіональних туристичних органів і місцевої влади. Таким чином, методи запобігання та планування дій на випадок ситуацій, а також методи боротьби з ними в разі їх виникнення, з тим щоб пом'якшити їх катастрофрічні наслідки, та оцінка ризиків стали і залишаться життєво важливим компонентом функціонування всіх підприємств в індустрії туризму. Серйозна криза може миттєво нанести шкоду репутації та привабливості подорожі, і зайняти роки для відновлення.

Важливо, щоб існував ряд превентивних заходів та систем підтримки прийняття рішень для реагування на непередбачені події і підвищення швидкості і ступеня, в якій підприємства і регіони оговтуються від цих інцидентів. Таким чином, основна проблема в методах запобігання та планування дій на випадок катастрофрічних ситуацій полягає в тому, щоб швидко знайти експертів, які мають досвід або знання в управлінні конкретною кризовою ситуацією. Однак навіть коли організації збирають такі знання, у них не завжди $є$ відповідні механізми для їх використання. Антикризове управління складається з трьох основних етапів, перерахованих нижче:

1) докризова стадія - виявлення потенційних кризових ситуацій і розробку кризових планів;
2) кризова стадія - управління безпосередньо кризовою ситуацією;

3) посткризовий етап - коригувальні та відновлювальні дії для відновлення довіри населення.

$€$ багато різних ідей або теорій про те, як найкраще впоратися 3 кризовою ситуацією [5]. Ці ідеї відрізняються, але, тим не менше, мають деякі загальні елементи:

1) необхідність передбачити потенційні кризові ситуації і готуватися до них;

2) необхідність надання точної і достовірної інформації під час кризи;

3) якомога швидше реагувати на ситуацію;

4) потреба у відповіді і необхідність довгострокових рішень.

Управління знаннями, яке, як вважалося, оптимально відповідає вищезгаданим вимогам, являє собою процес швидкого і зручного надання відповідної інорормації людям для продуктивного використання. Управління інформацією - це процес, який фоокусується на отриманні, розташуванні, зберіганні, пошуку і використанні інорормації для виробництва знань. Будь-яка успішна система управління знаннями буде вирішувати, як мінімум, такі концепції і проблеми: повторне використання, обмін, навчання і підвищення обізнаності, ідентифрікація користувачів, фрінансування і сприяння створенню нових знань.

Висновки. Загострення епідеміологічної ситуації в світі під час пандемії COVID19 призвело до різкого скорочення попиту на туристичні послуги, введення жорстких санітарних обмежень на відвідування туристичних дестинацій, а також до обмеження фрункціонування підприємств сорери розваг і відпочинку, громадського транспорту, сорери гостинно-ресторанного бізнесу. В результаті відбулося різке скорочення кількості міжнародних туристичних потоків і обсягу доходів від міжнародного туризму до державних бюджетів.

Дотримання медичних та санітарно-епідеміологічних рекомендацій, самодисципліна і самоорганізація, адміністрування та управління знаннями сприятимуть прискореному виходу туристичної галузі 3 кризи, відновлення фрункціонування туристичних підприємств в умовах пандемії COVID-19, запобігання поширенню епідемічної ситуації та інфрекційних захворювань серед туристів і широких верств населення, відновленню фрункціонування міжнародного туризму на якісно нових сервісних та інформаційних принципах. 


\section{СПИСОК ВИКОРИСТАНИХ ДЖЕРЕЛ:}

1. Державний комітет статистики України. URL: http://www.ukrstat.gov.ua/

2. Дивись.info. URL: https://dyvys.info/2020/05/14/turyzm-pislya-karantynu-yak-pandemiya-vplynula-na-galuzi-zminyla-yiyi/

3. Дутка Г. Я., Гальків Л. І., Козак Б. Б. Наукові дослідження з проблем міжнародного туризму: статистична бібліографрія наукових статей. Ефрективна економіка. 2018. № 12. URL: http://www.economy.nayka.com.ua/ ?op=1\&z=6724; DOI: https://doi.org/10.32702/2307-2105-2018.12.2.

4. Красовський С. О. Дослідження міжнародного туризму в дисертаційних роботах українських науковців. Українська культура: минуле, сучасне, шляхи розвитку. Культурологія. 2017. Вип. 25. С. 208-213.

5. МОЗ опублікувало рекомендації щодо організації роботи бізнесу з 11 травня. URL: https://buhgalter911.com/ uk/news/news-1050204.html?utm_source=gravitec\&utm_medium=push\&utm_campaign=Push:13.05.2020

6. Названі найнебезпечніші країни для туризму в 2020 році. URL: https://ua.korrespondent.net/lifestyle/ travel/4239328-nazvani-naibezpechnishi-krainy-dlia-turyzmu-v-2020-rotsi

7. UNWTO. World Tourism Organization. URL: https://www.unwto.org/tourism-covid-19

\section{REFERENCES:}

1. Derzhavnyi komitet statystyky Ukrainy. Retrieved from: http://www.ukrstat.gov.ua/ (in Ukrainian)

2. Dyvys.info [See.info]. Retrieved from: https://dyvys.info/2020/05/14/turyzm-pislya-karantynu-yak-pandemiya-vplynula-na-galuz-i-zminyla-yiyi/ (in Ukrainian)

3. Dutka H. Ya., Halkiv L. I., Kozak B. B. (2018) Naukovi doslidzhennia z problem mizhnarodnoho turyzmu: statystychna bibliohrafiia naukovykh statei [Scientific research on the problems of international tourism: statistical bibliography of scientific articles]. Efektyvna ekonomika, no. 12. Retrieved from: http://www.economy.nayka.com.ua/ ?op=1\&z=6724; DOI: https://doi.org/10.32702/2307-2105-2018.12.2 (in Ukrainian)

4. Krasovskyi S. O. (2017) Doslidzhennia mizhnarodnoho turyzmu v dysertatsiinykh robotakh ukrainskykh naukovtsiv [Research of international tourism in dissertations of Ukrainian scientists]. Ukrainska kultura: mynule, suchasne, shliakhy rozvytku. Kulturolohiia, 25, 208-213. (in Ukrainian)

5. MOZ opublikuvalo rekomendatsii shchodo orhanizatsii roboty biznesu z 11 travnia [The Ministry of Health has published recommendations on the organization of business from May 11]. Retrieved from: https://buhgalter911.com/ uk/news/news-1050204.html?utm_source=gravitec\&utm_medium=push\&utm_campaign=Push:13.05.2020 (in Ukrainian)

6. Nazvani nainebezpechnishi krainy dlia turyzmu v 2020 rotsi [Named the most dangerous countries for tourism in 2020]. Retrieved from: https://ua.korrespondent.net/lifestyle/travel/4239328-nazvani-naibezpechnishi-krainy-dliaturyzmu-v-2020-rotsi (in Ukrainian)

7. UNWTO. World Tourism Organization. Retrieved from: https://www.unwto.org/tourism-covid-19 